\title{
Influence of exogenous phytohormones, methyl jasmonate and suppressors of jasmonate biosynthesis on Agrobacterium-mediated transient expression in Nicotiana excelsior
}

\author{
Y. R. Sindarovska, I. M. Gerasymenko, M. V. Kuchuk, Y. V. Sheludko
}

Institute of Cell Biology and Genetic Engineering, NAS of Ukraine

148, Akademika Zabolotnogo Str., Kyiv, Ukraine, 03680

ysheludko@ukr.net

\begin{abstract}
Our aim was to investigate the influence of some exogenous agents on the recombinant protein accumulation in plants via Agrobacterium-mediated transient expression. Methods. Agrobacterium-mediated transient expression method, spectrophotometric methods for protein analysis, statistical calculations. Results. It was shown that the tested compounds in different concentrations (namely, auxins, cytokinin, methyl jasmonate and suppressors of jasmonate biosynthesis (phenidon and diethyldithiocarbamic acid)) added to the infiltration buffer did not influence either GFP transient expression nor total protein accumulation in plant tissue. Conclusions. The results suggest that the tested factors are not substantial for Agrobacterium-mediated transient expression.
\end{abstract}

Keywords: Nicotiana excelsior; Agrobacterium; transient expression; GFP.

Introduction. Agrobacterium-mediated transient expression represents a quick and efficient way of producing recombinant proteins in plants. This approach could be applied for rapid testing of genetic vectors or obtaining preparative amount of target proteins. Foreign gene expression occurs within several days after bacteria inoculation without transgene integration into the plant genome $[1,2]$. During recent decades the laboratory transient expression protocol has been adapted to commercial scale $[3,4]$ and a wide range of pharmaceutical proteins has been obtained including functional full-size antibodies [5]. Additionally, numerous applications of transient expression for the analysis of gene or promoter expression and regulation have been developed (see for review [6]).

A considerable attention paid to the optimization of transient expression protocol allowed the definition of

(c) Institute of Molecular Biology and Genetics, NAS of Ukraine, 2012 several groups of factors influencing the process efficiency. Among them, the physiological characteristics of both interacting partners, Agrobacterium and a hosting plant are important. For the latter it was shown that the plant age, leaf position and even location within the leaves may strongly modify the level of foreign protein accumulation $[7,8]$. The consideration of the most important production factors and the development of expression models allowed prediction of the target protein yield and calculation of the cost function for the production process that is necessary for the current good manufacturing practice protocol [9]. However, numerous factors influencing the level of transiently expressed proteins are still poorly studied, especially those concerning the phytohormone balance in the target plant tissue. It is well known that the phytohormone balance changes may regulate protein metabolism/catabolism as well as stress reactions in the plant cell [10]. Auxin influences the cell division and differentiation in many 
ways. Its action may be mediated via induction or repression of numerous specific genes and results in producing the proteins required for growth $[11,12]$. Another important phytohormone group, cytokinins, among other functions in plant organism may retard senescence. They are required during the greening process stimulating the chloroplast development and the expression of numerous genes [12-14]. All these factors may contribute to the biosynthetic capacity of plant tissue including general protein biosynthesis process during transient expression.

Jasmonates, the secondary messengers stimulated by wounding or pathogen attack, trigger an important cascade of stress reactions including the processes leading to protein degradation or de novo synthesis (the latter concerns first of all a wide range of plant defence proteins) [15]. Long term exposition of plant tissue to jasmonate signals causes general depression of translation, ribosome inactivation and decrease in the protein content [16]. This reaction foregoes tissue necrosis aiming at pathogen localization. The blocking of jasmonate-mediated stress reactions may impact protein biosynthesis in plant cell. Two substances, 1-phenyl-3-pyrazolidinone (phenidone) and sodium diethyldithiocarbamate (DIECA), have been selected as suppressors of jasmonate biosynthesis and, consequently, jasmonatemediated stress reactions. The first compound inhibits lipoxigenase, an enzyme of the early stages of jasmonate biosynthesis $[17,18]$. The second one reduces hydroperoxide derivative of linolenic acid removing this intermediate from jasmonic acid biosynthesis pathway. Several examples of the DIECA inhibitory effect on jasmonate mediated stress reactions have been described [17-19]. Infiltration with Agrobacterium may stimulate the jasmonate-mediated defensive processes, including repression of the total protein biosynthesis. Their blocking as well as enhancing could, therefore, influence the recombinant protein biosynthesis during transient expression.

To the best of our knowledge, no data exist on influence of the compounds mentioned above on Agrobacterium-mediated transient expression in plants. Here we describe the results of studying the GFP transient expression in $N$. excelsior after addition of exogenous phytohormones (auxins: indolyl acetic acid and 2, 4-dichlorophenoxyacetic acid; and cytokinin kinetin), me- thyl jasmonate and suppressors of jasmonate biosynthesis (1-phenyl-3-pyrazolidinone and sodium diethyldithiocarbamate) to the infiltration buffer.

Materials and methods. Plant material. Seeds of $N$. excelsior were obtained from the National Germplasm Bank of World Flora of the Institute of Cell Biology and Genetic Engineering (Ukraine). Plants were grown in greenhouse at $20-25^{\circ} \mathrm{C}$ and $14 \mathrm{~h}$ light period (3000-4000 lux). 8-10 week old plants were used in the experiments.

Bacterial strains and genetic constructs. An expression system included the plasmid pICH5290 carrying the reporter synthetic GFP gene driven by the CaMV $35 \mathrm{~S}$ promoter and the plasmid pICH6692. The plasmid pICH6692 contained the gene of $\mathrm{p} 19$ protein of tomato bushy stunt virus, a suppressor of post-transcriptional gene silencing [20] driven by the $35 \mathrm{~S} \mathrm{CaMV}$ promoter. All the mentioned plasmids were obtained for scientific purposes from Icon Genetics GmbH («Halle/Saale», Germany).

Agrobacterium tumefaciens strain GV3101 transformed with individual constructs was grown for 18$24 \mathrm{~h}$ at $100 \mathrm{rpm}$ in LB medium supplemented with $50 \mathrm{mg} / 1$ of rifampicin and $50 \mathrm{mg} / 1$ of carbenicillin or kanamycin, and $100 \mu \mathrm{M}$ of acetosyringone.

Transient expression assay. Plant infiltration was performed as described in the recent publication [21]. The Agrobacterium suspensions $\left(\mathrm{OD}_{600}=1.0\right)$ harboring pICH5290 and pICH6692 plasmid vectors were mixed in the equal volumes and the leaves of greenhouse grown plants were infiltrated with Agrobacteri$u m$ mixture $(\sim 50 \mu 1 /$ leaf $)$. The plants were further grown under greenhouse conditions and were harvested at $4^{\text {th }}$ day after infiltration. All experiments were carried out in 6-15 replications.

Treatment conditions. Indolyl acetic acid (IAA, «Sigma», Germany) was prepared as a $10 \mathrm{mg} / \mathrm{ml}$ stock solution in ethanol $(96 \%, \mathrm{~V} / \mathrm{V})$. Immediately before the experiment the stock solution was diluted with water to concentration $0.1 \mathrm{mg} / \mathrm{ml}$ IAA and added to the infiltration buffer so that the final concentrations were $0.5 \mathrm{mg} / \mathrm{l}, 1 \mathrm{mg} / \mathrm{l}$ and $5 \mathrm{mg} / \mathrm{l}$. Additionally, IAA was prepared as a $10 \mathrm{mg} / \mathrm{ml}$ stock solution in ethanol $(50 \%$, $\mathrm{V} / \mathrm{V})$, diluted with water to concentration $1 \mathrm{mg} / \mathrm{ml}$ and added to the infiltration buffer so that the final concentrations were 10 and $50 \mathrm{mg} / 1$. 
Table 1

GFP and TSP accumulation in N. excelsior after auxin treatments

\begin{tabular}{|c|c|c|}
\hline $\begin{array}{c}\text { Concentration, } \\
\mathrm{mg} / \mathrm{l}\end{array}$ & $\begin{array}{c}\mathrm{GFP}, \% \mathrm{TSP} \pm \text { standard } \\
\text { deviation }\end{array}$ & $\begin{array}{c}\text { TSP, } \mathrm{mg} / \mathrm{g} \text { raw } \\
\text { weight } \pm \text { standard deviation }\end{array}$ \\
\hline \multicolumn{3}{|c|}{$I A A$} \\
\hline 0 (control) & $5.42 \pm 1.42$ & $4.92 \pm 1.85$ \\
\hline 0.5 & $4.0 \pm 0.65$ & $5.29 \pm 1.73$ \\
\hline 1 & $4.87 \pm 1.72$ & $4.58 \pm 0.69$ \\
\hline 5 & $4.72 \pm 3.44$ & $4.66 \pm 1.36$ \\
\hline \multicolumn{3}{|c|}{$I A A$, high concentrations* } \\
\hline 0 (control) & $4.02 \pm 0.1$ & $7.0 \pm 2.35$ \\
\hline 10 & $5.66 \pm 2.89$ & $8.02 \pm 1.92$ \\
\hline 50 & $4.23 \pm 1.13$ & $8.67 \pm 3.79$ \\
\hline \multicolumn{3}{|c|}{$2,4-D$} \\
\hline 0 (control) & $1.94 \pm 1.36$ & $6.5 \pm 1.05$ \\
\hline 0.1 & $1.98 \pm 0.91$ & $5.89 \pm 0.89$ \\
\hline 0.2 & $1.83 \pm 0.51$ & $5.19 \pm 1.03$ \\
\hline 1 & $2.07 \pm 1.0$ & $5.43 \pm 1.6$ \\
\hline 2 & $2.65 \pm 1.0$ & $5.31 \pm 1.34$ \\
\hline
\end{tabular}

*The experiment was performed separately because of difference in the control treatment.

2,4-Dichlorophenoxyacetic acid (2,4-D, «Sigma») was prepared as a $10 \mathrm{mg} / \mathrm{ml}$ stock solution in ethanol $(50 \%, \mathrm{~V} / \mathrm{V})$, diluted with water to concentration $0.1 \mathrm{mg} / \mathrm{ml}$ and added to the infiltration buffer so that the final concentrations were $0.1 \mathrm{mg} / 1,0.2 \mathrm{mg} / 1,1 \mathrm{mg} / 1$ and $2 \mathrm{mg} / \mathrm{l}$.

Kinetin («Calbiochem», USA) was prepared as a $10 \mathrm{mg} / \mathrm{ml}$ stock solution in $0.1 \mathrm{~N} \mathrm{NaOH}$, diluted with water to concentrations $1 \mathrm{mg} / \mathrm{ml}$, and $0.5 \mathrm{mg} / \mathrm{ml}$ and added to the infiltration buffer in equal volume to the final concentrations of $1 \mathrm{mg} / \mathrm{l}$ and $2 \mathrm{mg} / \mathrm{l}$.

Methyl jasmonate (MJ, «Duchefa», Netherlands) was prepared as $50 \mathrm{mM}$ solution in $70 \%$ ethanol and added to the infiltration buffer to the final $100 \mu \mathrm{M}$ concentration.

Sodium diethyldithiocarbamate (DIECA, «Fluka», Germany) was prepared as $100 \mathrm{mM}$ stock solution in deionized water. The stock solution was added to the in- filtration buffer immediately after preparation to the final $1 \mathrm{mM}$ concentration.

1-Phenyl-3-pyrazolidinone (Phenidone, «Aldrich», Germany) was prepared as $20 \mathrm{mM}$ stock solution in degassed deionized water to prevent oxidation and was added to the infiltration buffer immediately after preparation to give the final concentrations 0.1 and $0.5 \mathrm{mM}$.

The respective amounts of deionized water or corresponding solvent were added to the buffer used for infiltration of control plants.

Protein extraction and GFP analysis. Accumulation of GFP in the infiltrated leaves was monitored with a hand-held black ray lamp (UVP, «Upland», USA) and the fluorescent areas were cut out. Protein extraction and GFP accumulation analysis were performed as described recently [7]. The concentration of total soluble proteins (TSP) was determined by the method of Bradford [22] using «BioPhotometer» («Eppendorf», USA). Bovine serum albumin was used as a standard protein.

Statistical calculations. For statistical data analysis the standard deviation and Student's test were used [23].

Results and discussion. For infiltration we used greenhouse grown $N$. excelsior plants. This species has good characteristics as a host for Agrobacterium-mediated transient expression [7]. Stock solutions of the tested compounds were added to the infiltration buffer prior to Agrobacterium injection into the plant tissue. After biomass harvesting, we monitored GFP and TSP accumulation in the infiltrated areas.

Influence of exogenous auxins on Agrobacteriummediated transient expression. Auxin stock solutions (IAA or 2,4-D) were added to the infiltration buffer to give the final concentrations of $0.1-5 \mathrm{mg} / 1$, which are applied usually in plant cell culture media and are close to the range of physiologically relevant means estimated for Nicotiana species [24, 25] or surpassing those (IAA, 10 and $50 \mathrm{mg} / \mathrm{l}$ ). No reliable effect on GFP accumulation as well as on total soluble protein content was detected after transient expression for all the tested concentrations of auxins (Table 1).

Influence of exogenous cytokinins on Agrobacteriummediated transient expression. Kinetin stock solution was added to the infiltration buffer to give the final concentrations applied usually in plant cell culture media $(1-2 \mathrm{mg} / \mathrm{l})$. These means surpass the upper range of 
Table 2

GFP and TSP accumulation in N. excelsior after kinetin treatment

\begin{tabular}{c|c|c}
\hline $\begin{array}{c}\text { Concentration, } \\
\mathrm{mg} / \mathrm{l}\end{array}$ & $\begin{array}{c}\text { GFP, \% TSP } \pm \text { standard } \\
\text { deviation }\end{array}$ & $\begin{array}{c}\text { TSP, mg/g raw } \\
\text { weight } \pm \text { standard deviation }\end{array}$ \\
\hline 0 (control) & $4.26 \pm 1.8$ & $6.8 \pm 1.45$ \\
1 & $5.11 \pm 3.28$ & $6.51 \pm 1.46$ \\
2 & $5.24 \pm 1.81$ & $6.25 \pm 0.87$ \\
\hline
\end{tabular}

Table 3

GFP and TSP accumulation in N. excelsior after MJ treatment

\begin{tabular}{c|c|c}
\hline $\begin{array}{c}\text { Concentration, } \\
\mu \mathrm{M}\end{array}$ & $\begin{array}{c}\text { GFP, \% TSP } \pm \text { standard } \\
\text { deviation }\end{array}$ & $\begin{array}{c}\mathrm{TSP}, \mathrm{mg} / \mathrm{g} \text { raw } \\
\text { weight } \pm \text { standard deviation }\end{array}$ \\
\hline 0 (control) & $4.18 \pm 2.74$ & $4.93 \pm 1.18$ \\
100 & $4.89 \pm 2.47$ & $5.01 \pm 1.15$ \\
\hline
\end{tabular}

Table 4

GFP and TSP accumulation in N. excelsior after phenidone and DIECA treatments

\begin{tabular}{c|c|c}
\hline $\begin{array}{c}\text { Concentration, } \\
\mathrm{mM}\end{array}$ & $\begin{array}{c}\text { GFP, \% TSP } \pm \text { standard } \\
\text { deviation }\end{array}$ & $\begin{array}{c}\text { TSP, mg/g raw } \\
\text { weight } \pm \text { standard deviation }\end{array}$ \\
\hline \multicolumn{3}{c}{ Phenidone } \\
0 (control) & $4.52 \pm 3.03$ & $6.7 \pm 2.34$ \\
0.1 & $3.95 \pm 1.28$ & $6.74 \pm 1.28$ \\
0.5 & $5.42 \pm 1.61$ & $6.03 \pm 1.24$ \\
& DIECA & \\
0 (control) & $2.5 \pm 1.86$ & $7.16 \pm 2.26$ \\
1 & $3.44 \pm 1.74$ & $5.45 \pm 3.48$ \\
\hline
\end{tabular}

physiologically relevant endogenous cytokinin concentration in tobacco plants [24, 26, 27]. As it was shown for auxins, no substantial change in GFP accumulation as well as in total soluble protein content was monitored after transient expression for all the tested concentrations of kinetin (Table 2).

Influence of exogenous MJ on Agrobacterium-mediated transient expression. In order to study the influence of exogenous jasmonate on the GFP transient expression we added stock solution of MJ to the infiltration buffer to give the final $100 \mu \mathrm{M}$ concentration commonly applied for plant elicitation [28]. Exogenous jasmonate caused no effect on GFP and TSP accumulation in $N$. excelsior after transient expression (Table 3).
Influence of suppressors of jasmonate-mediated stress reactions on Agrobacterium-mediated transient expression. Adding to the infiltration buffer of phenidone in concentration 0.1 and $0.5 \mathrm{mM}$ as well as DIECA in concentration $1 \mathrm{mM}$ did not cause changes in the transient expression level or total proteins content. Although the average GFP concentration slightly increased in phenidone $(0.5 \mathrm{mM})$ and DIECA treated plants in comparison with the control samples, the differences were not reliable (Table 4).

The data obtained suggest that the tested factors caused no reliable effect on the foreign protein transient expression efficiency as well as on the total protein biosynthesis during this process. Insignificant variety of protein concentration in different experiments may be explained by some heterogeneity of plant material or greenhouse conditions. It does not influence the result interpretation because the control treatment has been carried out for each experimental set. The results obtained show that the initial characteristics of plant organism (like plant age, leaf position etc.) used for transient expression play more important role than exogenous phytohormone treatments, because of either maintaining hormonal homeostasis in plant tissue or independence of transient expression processes from auxin/cytokinin reactions. Physiological abundance of endogenous jasmonates induced after agrobacterial infiltration may be a reason for the absence of response to the exogenous MJ treatment.

On the other hand, jasmonate biosynthesis blocking by phenidone or DIECA in the infiltration buffer may be inefficient at a stage of protein accumulation which starts usually on the second day after infiltration. The both substances are unstable and quickly degrade in physiological conditions.

Additionally, an intersection of different stress signaling pathways (for example, salicylate mediated defence network) can occur [29, 30].

Conclusions. The addition of auxins, cytokinins, $\mathrm{MJ}$ and suppressors of jasmonate-mediated stress reactions (phenidone and DIECA) to the infiltration buffer neither enhanced the GFP transient expression nor influenced the total protein accumulation in plant tissue. It suggests that these factors in the tested concentration are not substantial for Agrobacterium-mediated transient expression protocol. 
Я. Р. Сіндаровська, І. М. Герасименко, М. В. Кучук, Ю. В. Шелудько

Вплив екзогенних фітогормонів, метилжасмонату та супресорів біосинтезу жасмонату на Agrobacteriumопосередковану транзієнтну експресію в Nicotiana excelsior

\section{Резюме}

Мета. Дослідження впливу деяких екзогенних агентів на накопичення рекомбінантного білка в рослинах за допомогою Agrobacterium-опосередкованої транзієнтної експресії. Методи. Agrobactеrium-опосередкована транзієнтна експресія, спектрофотометричні методи для аналізу білків, статистичні розрахунки. Результати. Показано, шоо протестовані речовини, а саме - деякі концентрації ауксинів, цитокініну, метилжасмонату і супресорів його біосинтезу (фенідону і диетилдитіокарбамату), додані до інфільтраиійного буфера, не впливають на транзієнтну експресію GFP $i$ загальний рівень вмісту білка в рослинній тканині. Висновки. Результати свідчать, щзо протестовані фактори не є суттєвими для проведення Agrobacterium-опосередкованої транзієнтної експресї.

Ключові слова: Nicotiana excelsior, Agrobacterium, транзієнтна експресія, GFP.

Я. Р. Синдаровская, И. М. Герасименко, Н. В. Кучук, Ю. В. Шелудько

Влияние экзогенных фитогормонов, метилжасмоната и супрессоров биосинтеза жасмоната на Agrobacteriumопосредованную транзиентную экспрессию в Nicotiana excelsior

Резюме

Цель. Исследование влияния некоторых экзогенных агентов на накопление рекомбинантного белка в растениях с помощью Agrobacterium-опосредованной транзиентной экспрессии. Методы. Agrobacterium-опосредованная транзиентная экспрессия, спектрофотометрические методы для анализа белков, статистические расчетыл. Результаты. Показано, что тестируемые вещества, а именно - некоторые концентрации ауксинов, циитокинина, метилжасмоната и супрессоров его биосинтеза (фенидона и диэтилдитиокарбамата), добавленные к инфильтрационному буфеpy, не влияют на транзиентную экспрессию GFP и общий уровень содержания белка в растительной ткани. Выводы. Результаты свидетельствуют, что тестируемые факторы не являются существенными для проведения Agrobacterium-опосредованной транзиентной экспрессии.

Ключевые слова: Nicotiana excelsior, Agrobacterium, транзиентная экспрессия, GFP.

\section{REFERENCES}

1. Fraley R. T., Horsch R. B., Matzke A., Chilton M., Chilton W. S., Sanders $P$. $R$. In vitro transformation of petunia cells by an improved method of cocultivation with A. tumefaciens strains // Plant Mol. Biol.-1984.-3, N 6.-P. 371-378.

2. Horsch R. B., Klee H. J. Rapid assay of foreign gene expression in leaf discs transformed by Agrobacterium tumefaciens: Role of T-DNA borders in the transfer process // Proc. Natl Acad. Sci. USA.-1986.-83, N 12.-P. 4428-4432.
3. Gleba Y., Klimyuk V., Marillonnet S. Magnifection - a new platform for expressing recombinant vaccines in plants // Vaccine.2005.-23, N 17-18.-P. 2042-2048.

4. Gleba Y., Klimyuk V., Marillonnet S. Viral vectors for the expression of proteins in plants // Curr. Opin. Biotechnol.-2007.-18, N 2.-P. 134-141.

5. Giritch A., Marillonnet S., Engler C. van Eldik G., Botterman J., Klimyuk V., Gleba $Y$. Rapid high-yield expression of full-size IgG antibodies in plants coinfected with noncompeting viral vectors // Proc. Natl Acad. Sci. USA.-2006.-103, N 40.-P. 1470114706.

6. Sheludko Y. V. Agrobacterium-mediated transient expression as an approach to production of recombinant proteins in plants // Recent Pat. Biotechnol.-2008.-2, N 3.-P. 198-208.

7. Sheludko Y. V., Sindarovska Y. R., Gerasymenko I. M., Bannikova M. A., Kuchuk N. V. Comparison of several Nicotiana species as hosts for high-scale Agrobacterium-mediated transient expression // Biotechnol. Bioeng.-2007.-96, N 3.-P. 608-614.

8. Wroblewski T., Tomczak A., Michelmore R. Optimization of Agrobacterium-mediated transient assays of gene expression in lettuce, tomato and Arabidopsis // Plant Biotechnol. J.-2005.-3, N 2.-P. 259-273.

9. Buyel J. F., Fischer R. Predictive models for transient protein expression in tobacco (Nicotiana tabacum L.) can optimize process time, yield, and downstream costs // Biotechnol. Bioeng.2012.-109, N 10.-P. 2575-2588.

10. Schwechheimer C., Schwager K. Regulated proteolysis and plant development // Plant Cell Rep.-2004.-23, N 6.-P. 353-364.

11. Guilfoyle T. J., Hagen G. Auxin response factors // Curr. Opin. Plant Biol.-2007.-10, N 5.-P. 453-460.

12. Plant Biochemistry / Eds H. W. Heldt, F. Heldt.-Burlington, San Diego: Elsevier, 2005.-630 p.

13. Nath P., Sane V. A., Sane A.P., Trivedi P. K. Plant gene expression, regulation of // Encyclopedia of molecular cell biology and molecular medicine / Ed. R. A. Meyers.-Weinheim: WileyVCH Verlag GmbH \& Co. KGaA, 2005.-Vol. 10.-P. 307-355.

14. Haberer G., Kieber J. J. Cytokinins. New insights into a classic phytohormone // Plant Physiol.-2002.-128, N 2.-P. 354-362.

15. Memelink $J$. Regulation of gene expression by jasmonate hormones // Phytochemistry.-2009.-70, N 13-14.-P. 1560-1570.

16. Reinbothe S., Mollenhauer B., Reinbothe C. JIPs and RIPs: the regulation of plant gene expression by jasmonates in response to environmental cues and pathogens // Plant Cell.-1994.-6, N 9.P. 1197-1209.

17. Koch T., Krumm T., Jung V., Engelberth J., Boland W. Differential induction of plant volatile biosynthesis in the lima bean by early and late intermediates of the octadecanoid-signaling pathway // Plant Physiol.-1999.-121, N 1.-P. 153-162.

18. Heil M., Koch T., Hilpert A., Fiala B., Boland W., Linsenmair K. $E$. Extrafloral nectar production of the ant-associated plant, Macaranga tanarius, is an induced, indirect, defensive response elicited by jasmonic acid // Proc. Natl Acad. Sci. USA.2001.-98, N 3.-P. 1083-1088.

19. Farmer E. E., Caldelari D., Pearce G., Walker-Simmons M. K., Ryan C.A. Diethyldithiocarbamic acid inhibits the octadecanoid signaling pathway for the wound induction of proteinase inhibitors in tomato leaves // Plant Physiology.-1994.-106, N 1.P. 337-342.

20. Voinnet O., Rivas S., Mestre P., Baulcombe D. An enhanced transient expression system in plants based on suppression of gene 
silencing by the 19 protein of tomato bushy stunt virus // Plant J.-2003.-33, N 5.-P. 949-956.

21. Sindarovska Y. R., Gerasymenko I. M., Sheludko Y. V., Olevinskaja Z. M., Spivak N. Y., KuchukN. V. Production of human interferon alpha $2 \mathrm{~b}$ in plants of Nicotiana excelsior by Agrobacterium-mediated transient expression // Tsitol. Genet.-2010.-44, N 5.-P. 60-64.

22. Bradford M. M. A rapid and sensitive method for the quantification of microgram quantities of protein utilizing the principle of protein-dye binding // Anal. Biochem.-1976.-72.-P. 248-254.

23. Lakin F. G. Biometry.-Moscow: Vysshaya shkola, 1990.-350 p.

24. Smigocki A. C., Owens L. D. Cytokinin-to-auxin ratios and morphology of shoots and tissues transformed by a chimeric isopentenyl transferase gene // Plant Physiol.-1989.-91, N 3.-P. 808-811.

25. Novakova M., Motyka V., Dobrev P. I., Malbeck J., Gaudinova A., Vankova $R$. Diurnal variation of cytokinin, auxin and abscisic acid levels in tobacco leaves // J. Exp. Bot.-2005.-56, N 421.P. 2877-2883.
26. Scott I. M., Horgan R. Mass-spectrometric quantification of cytokinin nucleotides and glycosides in tobacco crown-gall tissue // Planta.-1984.-161, N 4.-P. 345-354.

27. Werner T., Motyka V., Strnad M., Schmulling T. Regulation of plant growth by cytokinin // Proc. Natl Acad. Sci. USA.-2001.98, N 18.-P. 10487-10492.

28. Gundlach H., Muller M. J., Kutchan T. M., Zenk M. H. Jasmonic acid is a signal transducer in elicitor-induced plant cell cultures // Proc. Natl Acad. Sci. USA.-1992.-89, N 6.-P. 2389-2393.

29. Smith J. L., De Moraes C. M., Mescher M. C. Jasmonate- and salicylate-mediated plant defense responses to insect herbivores, pathogens and parasitic plants // Pest Manag. Sci.-2009.-65, N 5.-P. 497-503.

30. Wasternack $C$. Jasmonates: an update on biosynthesis, signal transduction and action in plant stress response, growth and development // Ann. Bot.-2007.-100, N 4.-P. 681-697.

Received 20.08.12 